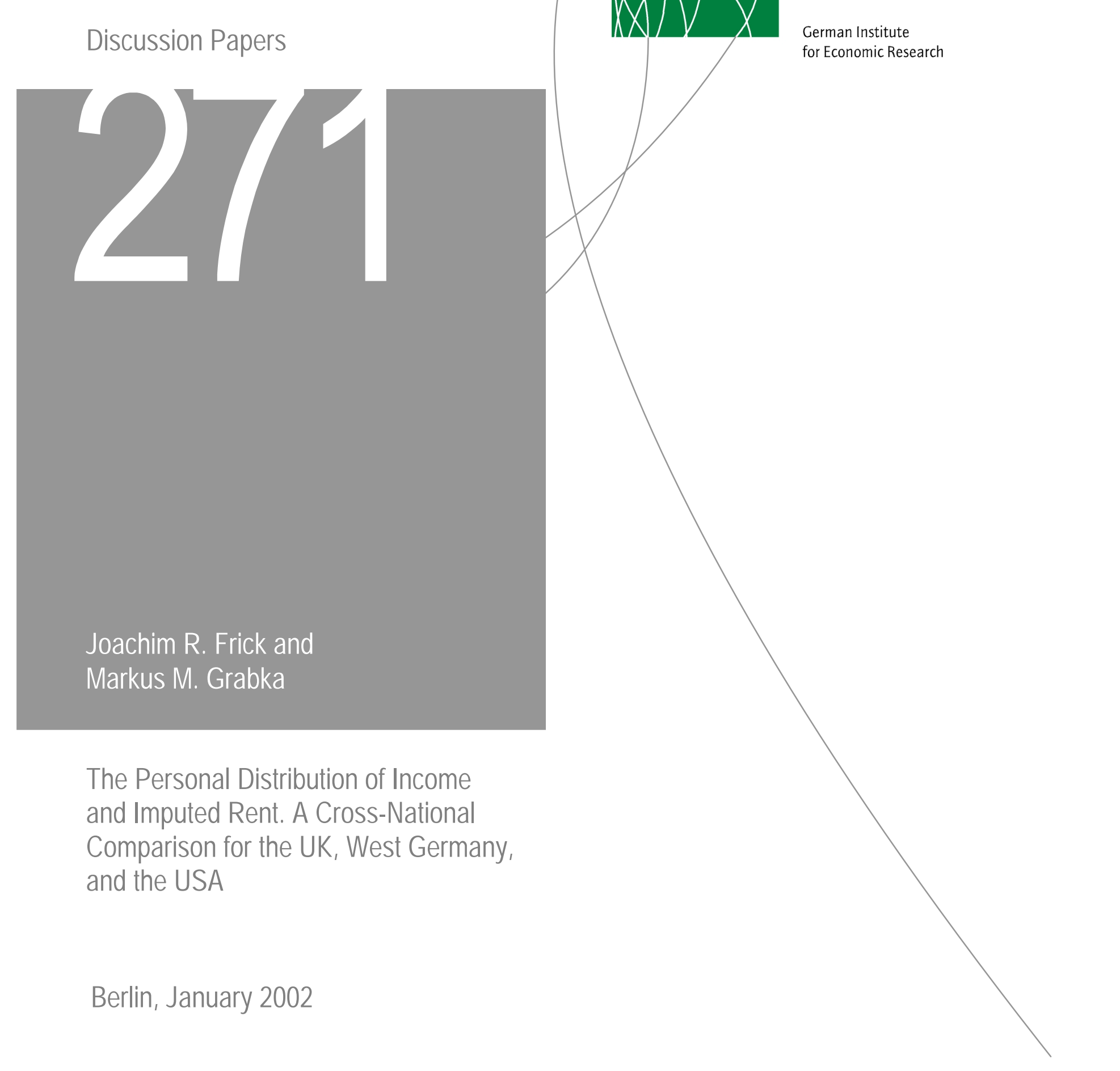


Opinions expressed in this paper are those of the author and do not necessarily reflect views of the Institute.

\section{DIW Berlin}

German Institute

for Economic Research

Königin-Luise-Str. 5

14195 Berlin,

Germany

Phone $+49-30-89789-0$

Fax +49-30-897 89-200

www.diw.de

ISSN 1619-4535 


\title{
The Personal Distribution of Income AND IMPUTed Rent - A Cross-National Comparison for the UK, WeSt Germany, AND THE USA
}

\author{
Joachim R. Frick and Markus M. Grabka
}

Berlin, January 2002

\begin{abstract}
Short Abstract
This article deals with income advantages derived from owner occupied housing (Imputed Rent, IR) and their impact on the personal income distribution. Following a brief description of different methods with which to calculate IR in household surveys, we conduct a cross-national comparative study based on micro-data from the British Household Panel Study (BHPS), the German SocioEconomic Panel (SOEP), and the US Panel Study of Income Dynamics (PSID). We find distinct differences between the Anglo-Saxon countries and Germany in terms of prevalence and extent of IR as well as in terms of the impact on the overall income distribution. In all three countries, however, using IR in measures of old age provision improves the quality of economic well-being assessment for the elderly.
\end{abstract}

JEL-Classification: D31, I31, R21

Keywords: $\quad$ Personal Income Distribution, Owner Occupied Housing, Imputed Rent, Old Age Provision

\section{Correspondence Address:}

Dr. Joachim R. Frick, DIW Berlin, Dept. Longitudinal Data and Microanalysis/SOEP, Königin-LuiseStr. 5, 14195 Berlin, Germany. Tel. +49-(0)30-89789-279 ; Fax: -109; email: jfrick@ diw.de Markus M. Grabka, DIW Berlin, Dept. Longitudinal Data and Microanalysis/SOEP, Königin-LuiseStr. 5, 14195 Berlin, Germany. Tel. +49-(0)30-89789-339 ; Fax: -109; email: mgrabka@diw.de 


\section{Summary}

As early as 1968 the United Nations argued in favor of capturing imputed rent (IR) from owner-occupied housing in national account statistics; in 1977 the UN issued guide-lines recommending the inclusion of this income type along with other property income.

International literature dealing with the impact of imputed rent on income inequality shows that the magnitude of this effect depends on (a) the population share of owner-occupiers, and (b) on the respective income advantage captured in the value of imputed rent. However, empirical results for Germany show this income advantage - measured as a share of postgovernment income - to vary from $2 \%$ to $27 \%$, depending on the method used (cf. Frick / Grabka 2001). In fact, existing household surveys around the world make use of a variety of ways to capture imputed rent, especially with respect to the treatment of owner-specific costs like taxes on real property, maintenance costs, and particularly interest on mortgages (see the claims for harmonization pushed by "The Canberra Group on Household Income Measurement", cf. Smeeding / Weinberg 1999 and 2001).

In this paper, we use data from three major national panel data sets, the British Household Panel Study (BHPS), the German Socio-Economic Panel Study (GSOEP), and the United States Panel Study of Income Dynamics (PSID). Keeping in mind that these surveys employ different approaches of measuring imputed rent and given the cross-national differences in terms of home-ownership rates, we first analyze the absolute and relative relevance of imputed rent as measured in the respective panel data sets - in contrast to a reference model where imputed rent is set to zero. Not surprising, our results indicate that IR is more prevalent in Anglo-Saxon countries than it is in Germany. Regarding the relevance of single income components, IR proves to be more important in the UK and the USA than it is in Germany. Applying some robust inequality indicators (Gini coefficient and Mean Logarithmic Deviation) to measure the impact of IR on the distribution of equivalent post-government income, we find a leveling effect in overall income inequality for Germany and a decrease in the US due to IR, which is in line with existing literature. However, we also find a somewhat reversed effect for the UK. Although we cannot rule out that this difference is partly driven by the methodological differences in measuring IR in the different surveys - clearly of importance is the different share of the relevant population of homeowners.

An important social policy issue in all three of these countries is the "aging society" phenomenon, which puts a lot of pressure on the national old age provision systems. There is an ongoing discussion, particularly in Germany with its strong public pension system, about whether or not to change the financing structure into a system which bears a greater resemblance to the "Anglo-Saxon model", which puts more emphasis on individual old age provision. By looking at the prevalence and magnitude of IR over the life cycle from a crossnational perspective, we find strikingly similar results for the UK and the USA with the German results showing the same structure, but at somewhat reduced levels. The inclusion of imputed rent in the discussion of relative income levels and the income distribution among the elderly clearly leads to an improved measure of economic well-being in the life span after retirement in all three countries.

The authors like to thank Richard V. Burkhauser, Stephen P. Jenkins, Birgit Otto, and participants of the International Conference of British Household Panel Study (BHPS) Users, University of Essex, UK, July 5-7, 2001 for helpful comments on an earlier draft of this paper. 


\section{Introduction and Motivation}

The income position of private households is not only influenced by monetary income, but also by non-monetary or in-kind income components. And although the significance of monetary income has been extensively analyzed in the international literature ${ }^{1}$, the topic of non-monetary income has not received the same scrutiny ${ }^{2}$, in part due to limited empirical data. One component of non-monetary income that takes on particular quantitative significance is imputed rents from owner occupied housing.

As early as 1968 the United Nations argued in favor of capturing imputed rent (IR) from owner-occupied housing in national account statistics; in 1977 the UN issued guide-lines recommending the inclusion of this income type along with other property income (cf. United Nations 1977). The „Canberra Group on Household Income Measurement" argues in favor of including imputed rent as a major income component of disposable income together with other in-kind income sources (cf. Smeeding / Weinberg 1999). International literature dealing with the impact of imputed rent on income inequality (cf. Yates 1994) shows that the magnitude of this effect heavily depends on (a) the population share of owner-occupiers ${ }^{3}$, and (b) on the respective income advantage captured in the value of imputed rent. However, empirical results for Germany show that this income advantage - measured as a share of postgovernment income - varies from $2 \%$ to $27 \%$, depending on the method applied (cf. Frick / Grabka 2001).

A major motivation for this study stems from the question of whether or not income advantages derived from owner occupied housing exacerbate or level out existing differences in income, thereby having an impact on individual income distribution as a whole. In other words: Is owner occupied housing more prevalent in the high-income population, thereby increasing income inequality, ceteris paribus? Smeeding et al. (1993) support evidence for a leveling effect on income distribution from imputed rents for Germany, Sweden, Canada and the Netherlands. Using the Theil index for Belgium, Meulemans and Cantillon (1993) show that income inequality declines, especially among the older population, after taking imputed rents into consideration. If interest payments are also included, then the decline in inequality of disposable income is even larger. Based on HBS data for selected EU-countries Eurostat (1998: 10-11) shows a poverty-reducing effect in 6 out of 7 observed EU countries triggered by the inclusion of net IR. For example, for Greece the share of persons under the $50 \%$ poverty threshold falls from $14,6 \%$ to $12,3 \%$. Studies for Australia, using the Household Expenditure Survey (HES), indicate that net imputed rent increases total household income of homeowners by $10 \%$ (Yates 1994). After including imputed rents, income inequality declines slightly: the Gini coefficient decreases from 0.39 to 0.38 . However, the income advantage is not distributed equally among all homeowners. Those owners who have attained complete ownership of their homes profit greatly from imputed rents, while the income advantage for homeowners still paying interest is relatively small. Use of net imputed rents can be recommended for studies on income over the lifetime of individuals.

\footnotetext{
${ }^{1}$ See, for example, Atkinson (1983), Atkinson / Rainwater / Smeeding (1995), Gottschalk / Schmeeding (1997), Cowell (2000).

${ }^{2}$ On the significance of non-monetary income see Smeeding et al. (1993) and Wolfe / Moffitt (1991).

${ }^{3}$ In large, the population share in owner occupied housing is increasing in all EU countries, last but not least for the purpose of old age provision. However, there is a high degree of heterogeneity from less than $50 \%$ in Germany to as much as about $80 \%$ in Spain.
} 
There are different ways to conceive of the economic advantages afforded by home ownership. On the one hand, owner occupied housing represents an income advantage in the sense that rent does not have to be paid. On the other hand, this can also be seen as a return on private investment in real estate instead of investing in the financial market. The ways in which to take such an advantage into account have been discussed for quite some time. ${ }^{4}$ In fact, existing household surveys around the world make use of a variety of methods to capture the monetary value of imputed rent; there are particularly strong differences in the various treatments of owner-specific costs like taxes on real property, maintenance costs, and particularly interest on mortgages. The difficulty lies in the different methods used to determine income advantages as well as in the varying extent to which these methods affect the income distribution. This is one reason why Smeeding / Weinberg (2001) feel a uniform definition of household income should be developed - especially for the purpose of crossnational comparative research. They state that, "if net imputed rent is included in income, one must be careful that it is measured in a way that leads to greater international standardization instead of nation-specific measures of its value" (Smeeding / Weinberg 2001: 12).

An important social policy issue in almost all industrialized countries is the "aging society" phenomenon, which puts a lot of pressure on the national old age provision systems. There is an ongoing discussion in Germany, with its strong public pension system, about whether or not to alter the financing structure so that it bears a greater resemblance to the "Anglo-Saxon" model, therefore increasing the importance of individual old age provision. By looking at the elderly population from a cross-national perspective, we will shed light on the question of to what extent the IR improves economic well-being after retirement.

Within the discussion of income advantages derived from owner occupied housing, the institutional framework, which has a very clear impact on the magnitude of the individual costs of housing, can, in principle, be taken into consideration. This includes not only subsidies for housing use (tax depreciation ${ }^{5}$ and direct subsidies), which are an advantage for homeowners, but also benefits for tenants, such as low-income housing, other forms of rent discounts, and company housing. Subsidizing the construction of low-income housing can be viewed as a form of government transfer because if the mechanisms for low-income housing support had been structured differently, individuals would likely have housing allowances instead. These aspects are not considered in the following analysis, which by no means reflects their lack of relevance. The purpose of this study is the comparison of various approaches for empirically calculating income advantages from owner occupied housing. We do not attempt to analyze the distribution of disposable income after taking housing costs and direct as well as indirect housing transfers into account.

This paper is structured as follows. After a brief description of different methods for determining income advantages from owner occupied housing, we empirically analyze prevalence and magnitude of IR based on micro-data from the British Household Panel Study (BHPS), the German Socio-Economic Panel (SOEP) and the American Panel Study of Income Dynamics (PSID). Changes in individual income positions as well as changes in the overall personal distribution of disposable equivalent income as a result of income advantages from owner occupied housing are presented for the three countries in light of the survey-specific

\footnotetext{
${ }^{4}$ See in particular Yates (1994). See McDonald (1994) for an overview of tax treatments of residences in the G-7 nations. E.g., the United Kingdom explicitly included imputed rent as part of the income tax base until 1963.

${ }^{5}$ E.g., the U.S. system allows home owners to deduct both mortgage loan interest and property taxes from the income on which federal income tax is paid.
} 
approaches used to determine IR. We further investigate the relevance of IR as a means of old age provision from a cross-national perspective. The final section concludes and gives recommendations for future research.

\section{Definitions and Alternative Procedures for Determining Imputed Rent}

The United Nations recommended, as early as 1968, that income advantages from owner occupied housing be included in national accounts. The following definitions formed the basis of that recommendation:

The total of owner-occupied dwellings which is to be included in gross output should, in principle, be valued at the rent on the market of the same facilities. It may be necessary to approximate the market rent by an estimate which should cover items such as operating, maintenance and repair outlays, water charges, insurance service charges, taxes, depreciation and mortgage interest in addition to interest on owner's investment in the dwelling and other elements of net return.(UN 1968 quoted according to Yates 1994:44).

This "aggregate income" approach, developed for international comparisons, assumes an estimate of gross rent and then deducts maintenance, operating, and insurance costs as well as taxes. In the context of calculating income distribution, income advantages from owner occupied housing (= imputed rent) should be classified as a component of the unearned income of private households. Imputed rent is therefore placed in the same category as income from interest, dividends and letting or leasing of property (United Nations 1977). The Canberra Group also recommends including imputed net rent in calculations of disposable income in international surveys (Smeeding and Weinberg 2001).

In principal one can distinguish between four different methods for calculating imputed rents:

- Market Value Approach

- Capital Market Approach

- Self-Estimation Approach

- Opportunity Cost Approach (Modified Market Value Approach)

\subsection{The Market Value Approach}

The market value approach, which is based on a comparative rent of "real" renters, is the procedure that has traditionally been used for calculating imputed rent (IR) in national accounts. In German national accounts, IR is calculated on the basis of surveys on rent from various statistics (buildings and housing surveys, micro-census, income and expenditure survey). Those expenditures of private households used for calculating average rents include costs for water, sewage, garbage disposal, street cleaning and other additional costs such as lighting, regardless of whether or not these costs are included in the rent. Costs for heating, hot water, and parking garages are not included. The households of homeowners are then assigned the resulting average rents according to selected criteria. Main criteria include the type of dwelling, the year the house was built, size, type of financing used, how the housing is equipped and regional information (see Hartmann 1992). 
National accounts have the aim both of calculating the total gross value added from letting or leasing housing and indicating income flows. The value of production is calculated for all occupied housing, including that which is owner occupied (imputed rents). The value of production of owner occupied housing is therefore calculated according to gross rents and overestimates the income advantages of owner occupied housing, because no owner related costs are deducted. ${ }^{6}$

\subsection{Capital Market Approach}

A second way to calculate income advantages from owner occupied housing has its starting point in the alternative use of capital on the capital market. A household's decision to move into homeownership represents a tradeoff whereby it has foregone the opportunity to invest in financial assets from which real income flows are created in the form of income from interest and dividends. Along the lines of the capital market approach, empirical calculation of the imputed interest from capital tied up as housing for homeowners is described by Saunders et al. (1992) as follows:

"Hence the implicit rate of return on housing equity will equal a safe private market rate of return ... on an equal value of investment. The annual rate of return which is used in this case is approximated by a two per cent real return (two percent above the change in overall consumer prices for a country in the year studied). Inflation plus two per cent was thus multiplied by home equity to estimate imputed rent." (Saunders et al. 1992: $11)$.

The capital market approach is applied in the "Anglo-Saxon" data sets we access in our analysis: the US-Panel Study of Income Dynamics (PSID) and the British Household Panel Study (BHPS). In the PSID, the current market value of owner occupied housing is estimated by the homeowner himself and outstanding credits, such as mortgages, are deducted from the estimated market value. If the resulting value is positive, an imputed rent is calculated on the basis of this value and an interest rate of $6 \%$ (see Butrica and Jurkat 1996).

Imputed rental value in the BHPS is also given as $6 \%$ of net equity of the owner-occupiers. Information on regional and county-level housing prices is used to construct estimates of current home value. In combination with house purchase and mortgage details from the respondents current outstanding mortgage debt and therefore net housing wealth or equity is created (see Henley 2000).

The problem with this approach is that it revolves around the estimation of the current market value of the property in the opinion of the homeowner, which makes objective estimation difficult. This is especially the case when the homeowners have been living in dwelling for a long period of time and are continuing to base their estimation on the original purchase price. The estimation of market value should, however, reflect the value of the object if it were to be sold now. A homeowner's high degree of affinity towards his or her own home makes a realistic estimation less likely. The danger of overestimation is very high. In addition, the failure to take depreciation into consideration as the building become older is a problem in this approach.

\footnotetext{
${ }^{6}$ According to Hartmann (1992), the share of imputed rents in the total value of production for the letting and leasing of housing was more than 52\% (about 212 billion DM) in 1990.
} 


\subsection{Self-Estimation Approach}

In this approach, the owner occupiers are asked directly to estimate the amount of rent that they would have to pay if they lived in their home as tenants. This estimate is then used as imputed rent. In the German Socio-Economic Panel (SOEP), for example, the following question is asked:

"And assuming that you lived in this apartment / house as a tenant: How high would the monthly rent be, not including heating costs?"

Estimation by the homeowner is also a problem in this approach because overestimation is certainly possible. Homeowners generally base their estimations on current discussions of rent for new tenants, especially when the housing market is strained, thus not taking into consideration the length of time they have lived in their home. This would normally lead to a reduction in the imputed rent calculated. However, to make this measure a meaningful one, owner-specific costs (financing, maintenance and repair, etc.) need to be deducted.

\subsection{Opportunity Cost Approach}

The opportunity cost approach for determining IR is based on the market value approach and is therefore also called the modified market value approach. All owner related costs are deducted from calculated average rents or comparable rents, which means that operating and maintenance costs (excluding heating), interest payments from the purchase of the home, and property taxes, etc. are all taken into account (see Yates 1994). It is particularly the deduction of interest payments within this net calculation that reduces the income advantage from owner occupied housing. Interest and mortgage payments are exceptionally important over the course of an entire lifetime, because, with time, total mortgage payments represent a higher percentage of the total mortgage that has to be paid off and the extent of actual ownership increases. As a result, older homeowners tend to benefit more from the income advantages of owner occupied housing. ${ }^{7}$

IR information used in our empirical analyses for Germany (SOEP) relies on a regression estimation of gross rent per square meter (not including heating) actually paid by main tenants in privately financed housing (without social housing and households with reduced rent). Indicators of dwelling condition, the year of construction, size, length of occupancy, the size of the town and disposable income are used as criteria for further classification. Based on these estimates IR is calculated for owner-occupiers, thereby avoiding distortions resulting from subjective estimation by the homeowners. Another advantage of this approach lies in the possibility to further differentiate than in the categorization method used in national accounts. All relevant costs (due to operation, maintenance and repair, and financing) are finally deducted from imputed gross rents without heating (for further details cf. Frick/Grabka 2001).

This approach is used as the basis for international comparative analyses of income distribution in a number of international data bases, such as in the European Community

\footnotetext{
${ }^{7}$ Negative IR values are generally not generated. In the case that owner related costs are higher than the income advantage (especially at the start of the mortgage repayment period when the burden of interest is highest), IR is assigned the value of zero.
} 
Household Panel (ECHP), the Belgian Panel Study (PSBH), the Data of the Panel Comparability Project (PACO) and the Luxembourg Income Study (LIS).

\subsection{Concluding Remarks}

The market value approach is suitable as a gross value for calculating IR in macroeconomic analysis and national accounts (value of production for the sector of letting and leasing of housing). The self-estimation approach, as well as the PSID version of the capital-market approach, both suffer from the normative decision on behalf of the interviewed owner occupiers. Additionally, the neglect of certain owner specific costs (costs for maintenance and repair) in the calculation of IR in the PSID and in the BHPS-data, very likely results in the overestimation of the income advantage of homeowners. ${ }^{8}$ The opportunity cost approach, however, appears to be more suitable for calculating IR as a net value for microeconomic analysis (such as for the individual distribution of disposable income). Thus, we must assume that the differential treatment of certain owner-specific costs in the data sets used in our empirical analyses, also affects the cross-national comparability of our results.

\section{Data and Methods}

The aim of the following empirical analyses is to measure the magnitude of IR in the three countries under consideration as well as the extent to which IR influences the national income distribution given the respective approach to calculate IR. Data is taken from the British Household Panel Study 9 (BHPS; see Taylor et al. 1998, or http://www.iser.essex.ac.uk/bhps), the German Socio-Economic Panel (SOEP; see SOEP-Group 2001, or http://www.diw.de/soep) and the Cross National Equivalent File (CNEF; see Burkhauser et al 2001, or http://www.human.cornell.edu/pam/gsoep/equivfil.cfm), the latter also providing the necessary information from the US Panel Study of Income Dynamics (PSID, see http://www.isr.umich.edu/src/psid/). Our analyses are made up by two points of measurement over a five-year period from 1993 to 1998 for the UK and Germany, and a four-year period from 1993 to 1997 for the USA ${ }^{10}$. Comparing two points in time is thought to provide some insight in the country specific development of private household investment in real estate.

The basic unit for the study is the individual in the context of his or her household. In order to better capture the selective effect of IR, we differentiate according to housing status and housing costs. The first differentiation is made between owners and tenants. Homeowners are then divided into two groups: persons in owner occupied households, who still have a mortgage on their home and have to make interest payments ("on mortgage"), and persons in homeowner households, who can claim complete ownership of their homes and therefore do not have to pay interest ("owned outright"). ${ }^{11}$

\footnotetext{
${ }^{8}$ A further developed measure of IR might be possible on the basis of both the capital market and self estimation approach with sufficient adjustment for owner related costs. Such applications of the capital market approach can be found in the Dutch Centraal Bureau voor de Statistiek (CBS) (see van de Donk 1994).

${ }^{9}$ We are most grateful to Stephen P. Jenkins for providing us with yearly BHPS income data.

${ }^{10}$ Since 1997 interviews in the PSID are carried out in a 2 year interval, so there is no 1998 information.

${ }^{11}$ Although Frick and Grabka (2001) provide arguments for differentiating the group of tenants into those paying rent and those living in rent-free housing, we abstain from doing so for the sake of cross-national comparability.
} 
Disposable income as of the previous year is turned into equivalent income by applying an equivalence scale with an elasticity of $\varepsilon=0.5$, given by the square root of the number of persons in the household. Comparing the results of our reference model excluding imputed rent and with those of an income measure including imputed rent gives a first glimpse at the importance of IR for the whole population as well as for the different subpopulation of interest. We add information on the relative income position (compared to the total population) and on IR as a percentage of disposable income. In order to measure the impact of IR on the overall personal income distribution, we apply various robust inequality indexes (Gini, decile ratios and mean log deviation) ${ }^{12}$.

Finally, in order to check for the relevance of home ownership as a means of old age provision we look at the distribution of IR over the life cycle and the relevance of IR for different age groups.

\section{Results}

The distribution of housing status and housing costs among the population in private households serves as the starting point for evaluating the effects of IR in the three countries (see Table 1). Over the observation period from 1993 to 1997/98, the share of the population living in owner-occupied housing slightly increased in all three countries about 2-3\%-points.

The results for the UK and the US look very similar. The share of the population living in owner-occupied housing is about $70 \%$ in both countries. Roughly two thirds of all owneroccupiers, that is about $50 \%$ of the total population in both countries, are still paying off mortgages; the remaining households own their home outright.

The ownership rate in West Germany is recognizable lower than in the Anglo-Saxon countries with less than $50 \%$ of the total population, i.e. far more than half of the West German population lives in rented accommodation. In contrast to the UK and the US results, the share of German homeowners who are still paying off mortgages is considerably lower (about 55\% of all owners).

In principle, the share of persons with a positive value of IR is by definition less than or equal to the total share of owner occupiers. However, due to the very high financing costs at the beginning of the repayment period it must be assumed that a certain portion of owneroccupiers does not realize any gains from imputed rent. According to our results, almost two thirds of the UK and the US population receive this fictitious income advantage, which is obviously higher than in Germany with about one third. ${ }^{13}$

\footnotetext{
${ }^{12}$ In order to reduce the effect of outliers (including incorrectly measured values), we apply a bottom and top trimming at the $1^{\text {st }}$ and the $99^{\text {th }}$ percentile, respectively.

13 Comparing the "ownership-rate" and "population share with a positive value of IR" in Table 1 for 1997/98, it appears that about $93 \%$ of US homeowners enjoy returns from owner-occupied housing, whereas this share is only $86 \%$ in the UK and as low as $73 \%$ in West Germany. We cannot rule out that these differences are partially caused by the different methods applied to determine IR. This is especially true for the German case with the allinclusive consideration of owner specific costs in the opportunity-cost approach.
} 


\subsection{Imputed Rent and Individual Income}

\subsubsection{Results from the Reference Model without Imputed Rent}

Not surprisingly, persons in homeowner households have a higher disposable income than those in tenant households; this is true for all three countries (see Table 2). The relative income position of owner-occupiers in the reference model (i.e., without considering IR) in all three countries is stable between 111 and $113 \%$ of the respective population average. The income position of owner-occupiers who had mortgages is even much higher than for those who owned outright. As an illustration, in West Germany 1993 the difference between owners with mortgages and those who own outright in the reference model is about 19 points (100 and 119, respectively). The higher income position of owners with mortgages is the result of the underlying lifecycle or age selectivity, given that these persons are by in large successfully integrated in the labor market, while the majority of outright owners are living on old age pensions. This result is very pronounced for the US, where outright owners appear to life on income below average.

As a consequence of the high-income position of owners, renters are clearly underperforming. In contrast to the surprising cross-country similarity of owners' position in the income distribution, it seems remarkable that the incomes of these two groups deviate much more in the Anglo-Saxon countries than they do in Germany. While in the latter country this group has an income position of almost 90, the financial status of renters in the UK and the US is just about $70 \%$ of the population average. However, the smaller proportion of German homeowners contributes to this result.

\subsubsection{The Impact of Imputed Rent on the Individual Income}

The methods to compute imputed rental values applied in the data bases used in this paper do not allow for negative values. As a result, the income advantage of persons in owneroccupied housing increases by definition once IR is considered (see Table 2). However, due to the above mentioned age selectivity, this increase in the income position mainly favors owners who own outright. On the other hand, owners on mortgage basically remain at the same relative income level as in the reference model without IR. Here, the high proportion of carrying charges, i.e. the mortgage interest payments, are the driving factors. In the UK, the population owning outright improves the income position due to IR by about $14 \%$-points in both observation years; in West Germany and the US this gain is about 8-10\%-points. This result for the US is most obviously related to the more pronounced income inequality, which other things being equal - reduces the probability of improving the relative income position. ${ }^{14}$

As a consequence of the increasing relative income levels of owner-occupiers, the position of renters deteriorates when IR is taken into consideration. In line with the above mentioned changes for homeowners, the population of tenants in the UK and the US loses about 6-8 index points, whereas in Germany this loss in relative well-being is only 3-4 index points.

\footnotetext{
${ }^{14}$ As a whole, the increase in the IR-measures in the three countries over the 5-year period is in line with the change of the post-government income without IR. As such, potential changes in the real estate market in the observed years do not seem to affect the scope of IR at all.
} 
A straightforward measure of relative importance of IR for the individual in its household context is "IR as a percent of Post-Government Income" (see Table 3). We find distinct cross-national differences for the total population: While in the UK imputed rent makes up as much as 9\% of total income in 1993 as well as in 1998, this result is about 7-9\% for the US and only 3-4 \% in West Germany. Clearly, this figure is influenced by Germany's proportion of owner-occupiers being lowest among all countries.

Renters by definition do not enjoy income advantages from IR. Thus, it is of interest to analyze separately the effect of IR on the income of all owner-occupiers as well as on the income of subgroups of owners. In line with our expectations, the relevance of IR for owners with mortgages is considerably lower than for those who own outright. For those who are still paying off mortgage, IR is about 8-9\% in the UK and in the US while the mostly elderly homeowners "gain" about 16-24\%. The corresponding numbers for Germany are substantially lower at about $2-4 \%$ and $12-15 \%$, respectively. This is a clear indication for the importance of this income advantage for elderly owners based on the implicit relevance of full carrying charges for private real property.

\subsection{Results from the Analysis of Income Distribution}

We analyze the effects of IR on the income distribution by comparing the results of robust inequality measures for two income concepts: equivalent post-government excluding IR (Reference Model) and including IR. Additionally, it should be kept in mind that our results are based on two different approaches for determining IR.

It should be noted that the results for our reference model (see Table 4) are in line with the international literature on income distribution (for the US cf. Burkhauser et al 1999; for the UK cf. Bardasi et al. 2000; and for Germany cf. SVR 2000). In short, inequality of equivalent post-government income is highest in US, the UK is in an intermediate position, and Germany shows the lowest level of inequality among the three countries. Concerning the development over time we also observe the expected results: increasing inequality among the US-American population and a slight decrease in inequality in the U.K. The German figures for 1993 and 1998 are rather stable.

The inclusion of IR yields a slight decrease in income inequality for Germany and a somewhat more pronounced reduction for the US which is in line with the findings in the literature (see Section 1). According to all measures employed, inequality in disposable income decreases once IR is taken into account. The Gini coefficient for 1993 in Germany, for example, has fallen from .2536 in the reference model to .2519. This effect is also true for 1998, where for example the MLD coefficient drops from .1184 by .0017 . The decrease in income inequality due to IR in the US is much more distinct with the Gini coefficient for 1997 dropping significantly from .4020 by as much as .0098 . The extraordinary high level of inequality given by the 90:10 Decile ratio in the reference model for 1997 , i.e. 12.35 , is reduced to "only" 9.27. A closer look at different segments of the income distribution given by the 90:50 and the 50:10 Decile ratio, respectively, reveals that the overall reduction of inequality is triggered by the leveling effect of IR among low income households.

However, the picture is dissenting for the UK where - if any at all - a minor increase in inequality can be observed for all measures applied. For example, the Gini coefficient for the UK in 1993 marginally increases by about .0012 when IR is brought in (in 1998 this 
difference is somewhat bigger at .0020). Using Decile ratios, we find for the UK that this effect is basically spread across the entire personal income distribution and does not apply to a certain income segment.

\subsection{Imputed Rent as a means of old age provision?}

An important social policy issue in all three countries considered in this analysis is the "aging society" phenomenon, whereby a lot of pressure is put on the national old age provision systems. There is an ongoing discussion, not only in Germany with its strong public pension system, about whether or not to change the financing structure into a system which bears a greater resemblance to the "Anglo-Saxon model", thus putting more emphasis on individual provision for one's old age. As an incentive for this, one argument is to publicly subsidize private investment into owner-occupied housing. The following analysis tries to give some empirical cross-national evidence for this discussion by focussing on the relevance of IR (see Table 5 and the illustration given in Graph 1) and on IR-induced changes in the relative income position over the life cycle (see Graph 2).

As expected we find a positive correlation between age of household head and positive values for Imputed Rent in all three countries. While this relationship is very strong in Germany, the trends for the UK and the US are less pronounced. Especially in the UK, we find IR to be more equally distributed over age cohorts. Concentrating on the households of the elderly, it appears to be the case for all countries that households headed by 66 to 75 year-olds have the highest proportion of owner occupiers (with positive values of IR). Also in common for all countries is that the oldest age cohort has a markedly lower share of owner-occupiers. This result may be driven by a variety of factors:

- old age regional mobility to the households of their children (mostly after the death of the partner)

- old age regional mobility into nursing homes

- donation of formerly owned property to children ("early inheritance") with lifelong usufructuary right to the housing as rent-free tenant

Graph 2 shows rather similar age-specific relative income positions in the reference model for all three countries. As expected, inequality appears to be most pronounced in the US.

Additionally, the corresponding changes in the relative income position are depicted after considering IR. Again, the trend for all three countries looks quite similar. The younger the household head, the bigger the relative loss in the income position after IR is taken into account. Households with middle-aged heads (age 46 to 55) mark a turning point and towards the upper end of the age distribution, relative gains increase when IR is taken into consideration. Due to the much lower share of owner-occupiers in Germany, the group specific changes appear less distinct. The changes of income position for elderly in the US are quite strong, which is due to the distinctively low income position in the reference model. As such, especially in the US imputed rent appears to be a most important, inherent part of the disposable income for the elderly. 


\section{Summary and Recommendations}

The aim of this analysis was to measure the magnitude of IR in the three countries under consideration as well as the extent to which IR influences the national income distribution given the respective approaches to calculating IR.

Empirical results for UK, West Germany and the US show that IR is a prevalent component of non-monetary income: In the Anglo-Saxon countries approximately two out of three persons live in households with positive imputed rental values, in West Germany this figure is only about one out of three. We also provide evidence that imputed rent is an important part of disposable income for owner-occupiers. The share of imputed rent in disposable income is, on average, between $3 \%$ and $15 \%$ in Germany and between $8 \%$ and $24 \%$ in the UK and the US, depending on the mortgage repayment status. ${ }^{15}$

In line with a number of empirical findings in the international literature, the results for West Germany and the US indicate that the inclusion of IR leads to a decrease in income inequality. However, we do find a deviating picture in the UK even though not significant.

Looking at the prevalence and magnitude of IR over the life cycle from a cross-national perspective, we find strikingly similar results for the UK and the USA while the German results have the same structure, but at a reduced magnitude. Especially among the elderly, the inclusion of imputed rent yields an improvement in the measurement of their economic wellbeing. While this is true in all three countries, this effect is clearly highest among the US elderly.

Future studies of the effect of IR on individual income and income distribution should reflect current discussions regarding international comparisons of income. The Canberra Group on Household Income Measurement (see Smeeding / Weinberg 2001), for example, describes the different methods currently being used for calculating and measuring IR in international household surveys and other data sets. We cannot rule out that the empirical results presented in this paper are partly attributed to methodological differences in the measurement of IR (capital-market approach in the cases of the UK and the US vs. opportunity cost approach in the case of Germany). As such, a standardized method for calculating and measuring IR should therefore be of major concern to producers and analysts of cross-nationally comparative income data. ${ }^{16}$

Finally, one might also include the idea of defining IR for tenants in rent-free housing. This seems to be useful for analyses, which explicitly focus on the life cycle of individuals, and especially for longitudinal analysis of income mobility. The income advantage for owners who have handed over the deeds of their property to their children and other beneficiaries of rent-free housing are lost, ceteris paribus, if IR is not calculated for tenants in rent-free housing. ${ }^{17}$

\footnotetext{
${ }^{15}$ Within this context, it would be worthwhile to include IR for all property for persons with more than one home for their own use. This study has generated income advantages only for the primary residence of homeowners. ${ }^{16}$ Given the rather small share of tenant households in the private housing market for countries like the UK (i.e, leaving aside the publicly subsidized housing market), it deems impossible to sensibly apply the opportunity cost approach.

${ }^{17}$ Frick / Grabka (2001) show for Germany that an alternative specification of the opportunity cost approach which also gives imputed rental values to tenants in rent-free housing further reduces income inequality measures: e.g. for West Germany 1998 the Gini coefficient in the reference model (without IR) was .2798, when
} 


\section{References:}

Atkinson, Anthony B. (1983): The Economics of Inequality. 2. Edition., Oxford.

Atkinson, Anthony B.; Rainwater, Lee; Smeeding, Timothy M. (1995): Income Distribution in OECD Countries. Paris: OECD.

Bardasi, Elena, Stephen P. Jenkins, and John A. Rigg (2000): Retirement and the Economic WellBeing of the Elderly: A British Perspective, ISER-Working Paper 2000-33, University of Essex.

Burkhauser, Richard V.; Buttler, J.S. and Houtenville, Andrew J. (1999): Changes in Permanent Income Inequality in the United States and Germany in the 1990s. Vierteljahrshefte zur Wirtschaftsforschung, 68(2): 284-289.

Burkhauser, Richard V.; Butrica, Barbara A.; Daly, Mary C. and Lillard, Dean R. (2001): The CrossNational Equivalent File: A product of cross-national research. In: Becker, I.; Ott, N. and Rolf, G. (Eds.): Soziale Sicherung in einer dynamischen Gesellschaft. Festschrift für Richard Hauser zum 65. Geburtstag, Frankfurt/New York: Campus, pp. 354-376.

Butrica, Barbara; Jurkat, Detlef (1996): Codebook for PSID-GSOEP Equivalent File 1980-1994. Syracuse University.

Cowell, Frank A. (2000): Measurement of Inequality. In: Atkinson, A. B. and Bourguignon, F. (Eds.): Handbook of Income Distribution, Amsterdam et al: Elsevier, pp. 87-150.

Eurostat (1998): Recommendations on Social Exclusion and poverty statstics. $31^{\text {st }}$ Meeting of the statistical programme committee. Luxembourg, 26 \& 27 November 1998. CPS 98/31/2, Luxembourg.

Frick, Joachim R. und Grabka, Markus M. (2001): Der Einfluß von Imputed Rent auf die personelle Einkommensverteilung. In: Jahrbücher für Nationalökonomie und Statistik, 221(3): 285-308.

Gottschalk, Peter and Smeeding, Timothy M. (1997): Cross-National Comparisons of Earnings and Income Inequality. Journal of Economic Literature, Vol. XXXV (June): 633-687.

Hartmann, Norbert (1992): Berechnung der Wohnungsmieten in den Volkswirtschaftlichen Gesamtrechungen. Wirtschaft und Statistik, 2, 65-72.

Henley, Andrew (2000): Housing Equity Data Computed from Waves 1 to 8 of the British Household Panel Survey. ISER-Working paper: University of Essex.

McDonald, John F. (1994): Tax Treatments of Residences: An International Comparison. In: Illinois Real Estate Letter, Winter/Spring 1994, pp. 8-10.

Meulemans, Bert and Cantillon, Bea (1993): De geriusloze kering: De nivellering van de intergenerationele welvaartsverschillen (Levelling of Intergenerational Inequality). Economisch en Social Tijschrift, (3): 421-448.

SOEP Group (2001): The German Socio-Economic Panel (GSOEP) after more than 15 years Overview. Vierteljahrshefte zur Wirtschaftsforschung, 70(1): 7-14.

Saunders, Peter et al. (1992): Noncash Income, Living Standards, Inequality and Poverty: Evidence from the Luxembourg Income Study. Discussion Papers No. 35, Social Policy Research Centre (SPRC), The University of New South Wales, Australia.

Smeeding, Timothy M.; Saunders, Peter; Coder, John; Fritzell, Johan; Hagenaars, Aldi J.M.; Hauser, Richard and Wolfson, Michael (1993): Poverty, Inequality, and Family Living Standards Impacts across seven Nations: The Effect of Noncash Subsidies for Health, Education, and Housing. Review of Income and Wealth, 39(3): 229-256.

allowing IR for homeowners with positive net equity only this measure was .2785 , and finally when allowing IR for rent-free tenants as well it was further reduced to .2773 . 
Smeeding, Timothy M.; Weinberg, Daniel H. (1999): Income Data Collection in International Household Surveys. Paper prepared for the Canberra Group on Household Income Measurement meeting in Ottawa, Canada, June 1999.

Smeeding, Timothy M.; Weinberg, Daniel H. (2001): Toward a Uniform Definition of Household Income. Review of Income and Wealth, 47(1): 1-24.

SVR (Sachverständigenrat zur Begutachtung der gesamtwirtschaftlichen Entwicklung) (2000): Chancen auf einen höheren Wachstumspfad. Jahresgutachten 2000/01. Metzler und Poeschl: Wiesbaden.

Taylor, Marcia F. (Ed.) (1998): British Household Panel Survey User Manual. Introduction, Technical Reports and Appendices. Colchester: University of Essex, ESRC

United Nations (1977): Provisional Guide-lines on Statistics of the Distribution of Income, Consumption and Accumulation of Households. Studies in Methods. Series M. No. 61. New York.

Van de Donk, Piet L. (1994): Huurwaarde als inkomen in natura: een ramingsmethode [= Imputed rent as income in kind: an estimation procedure]. Supplement bij de Sociaal-economische maandstatistiek, pp. 5-13.

Wolfe, Barbara und Moffitt, Robert (1991): A New Index To Value In-Kind Benefits. Review of Income and Wealth, 37(4): 387-408.

Yates, Judith (1994): Imputed Rent and Income Distribution. Review of Income and Wealth, 40 (1): 43-66. 


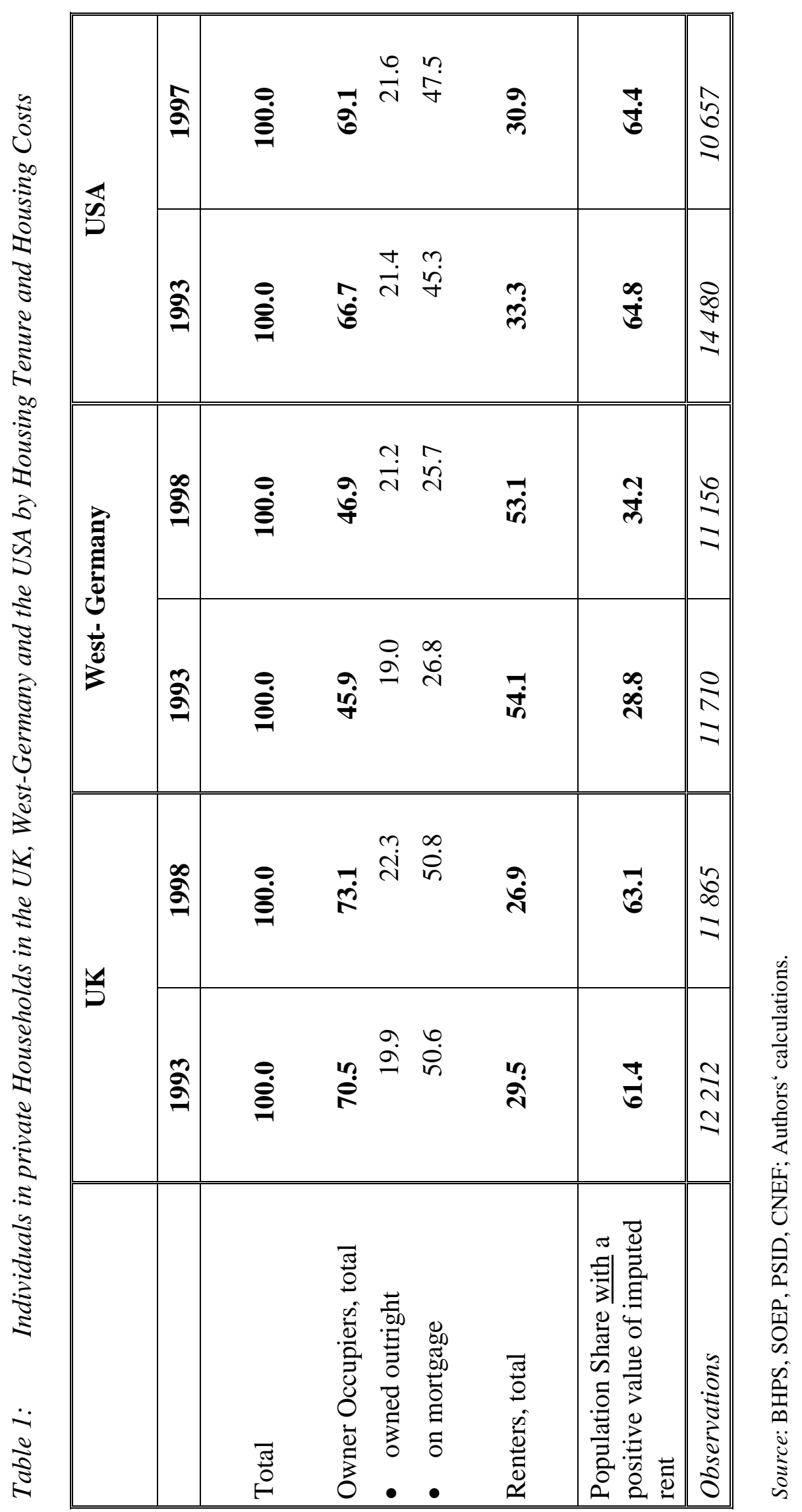




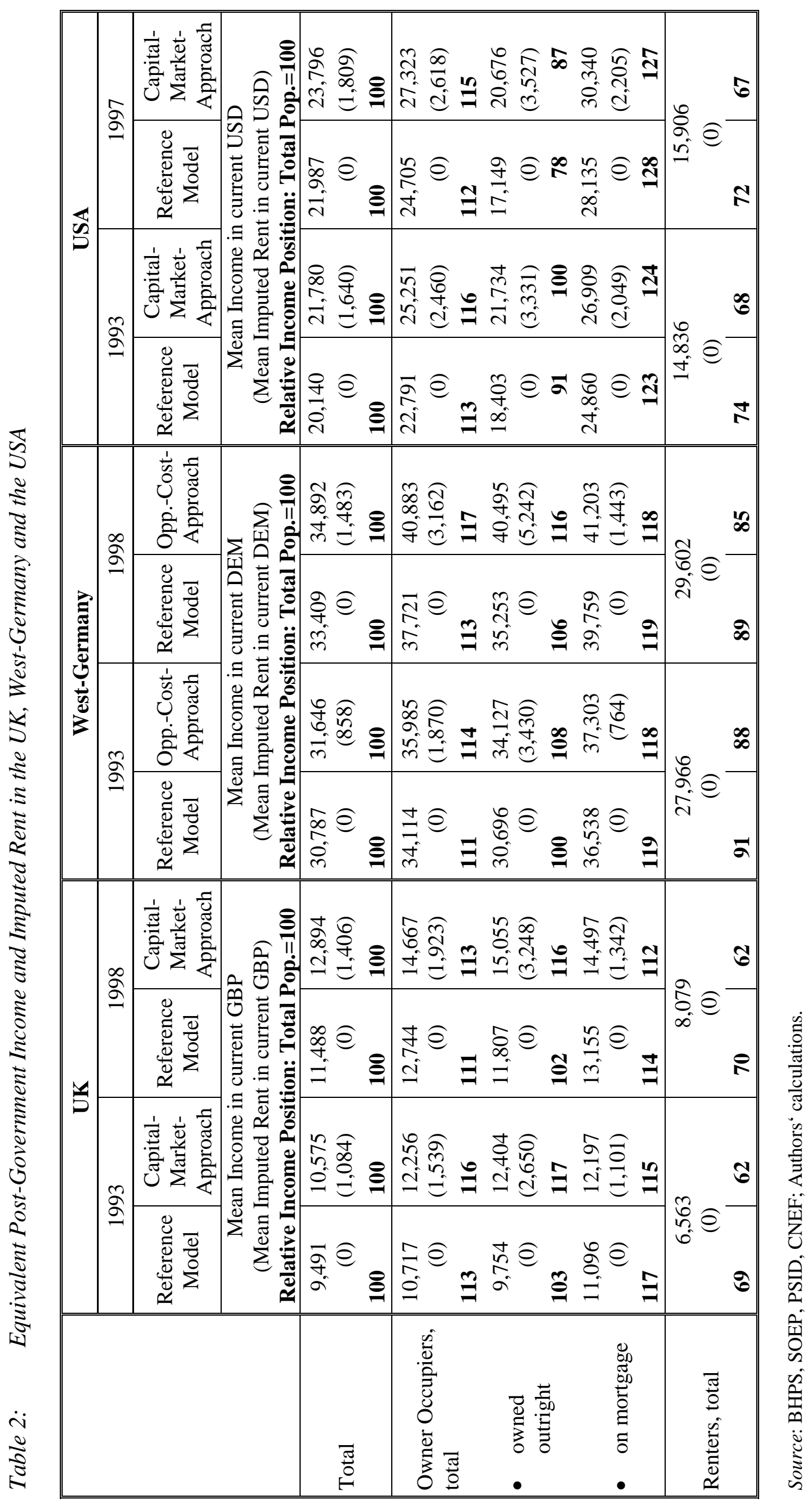




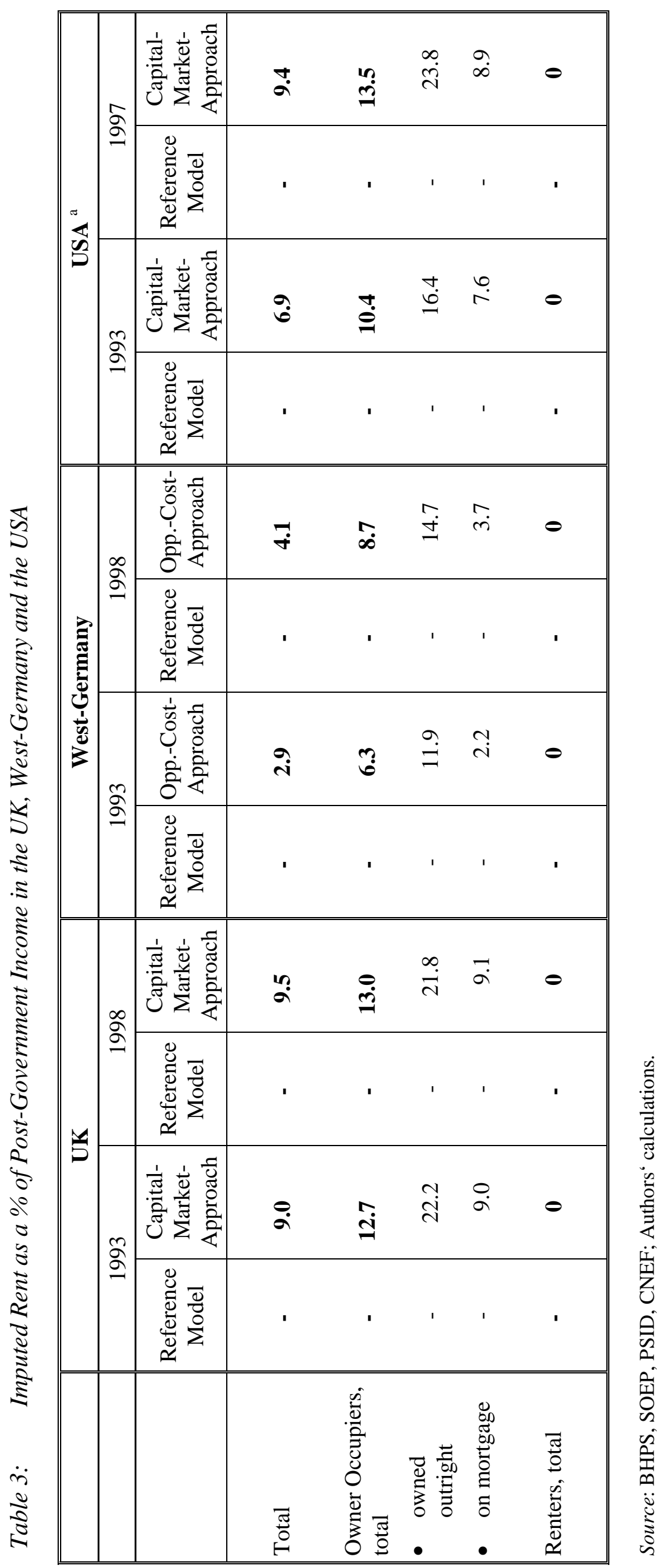




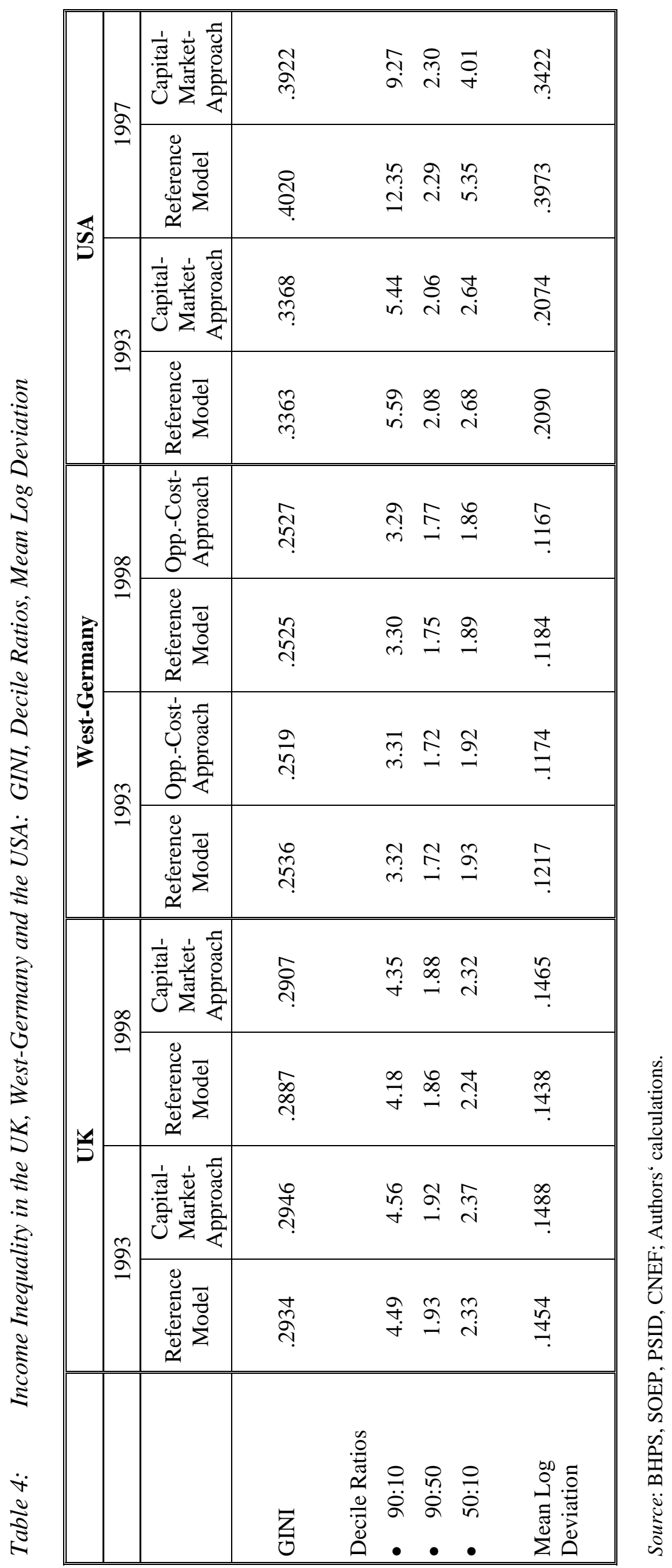




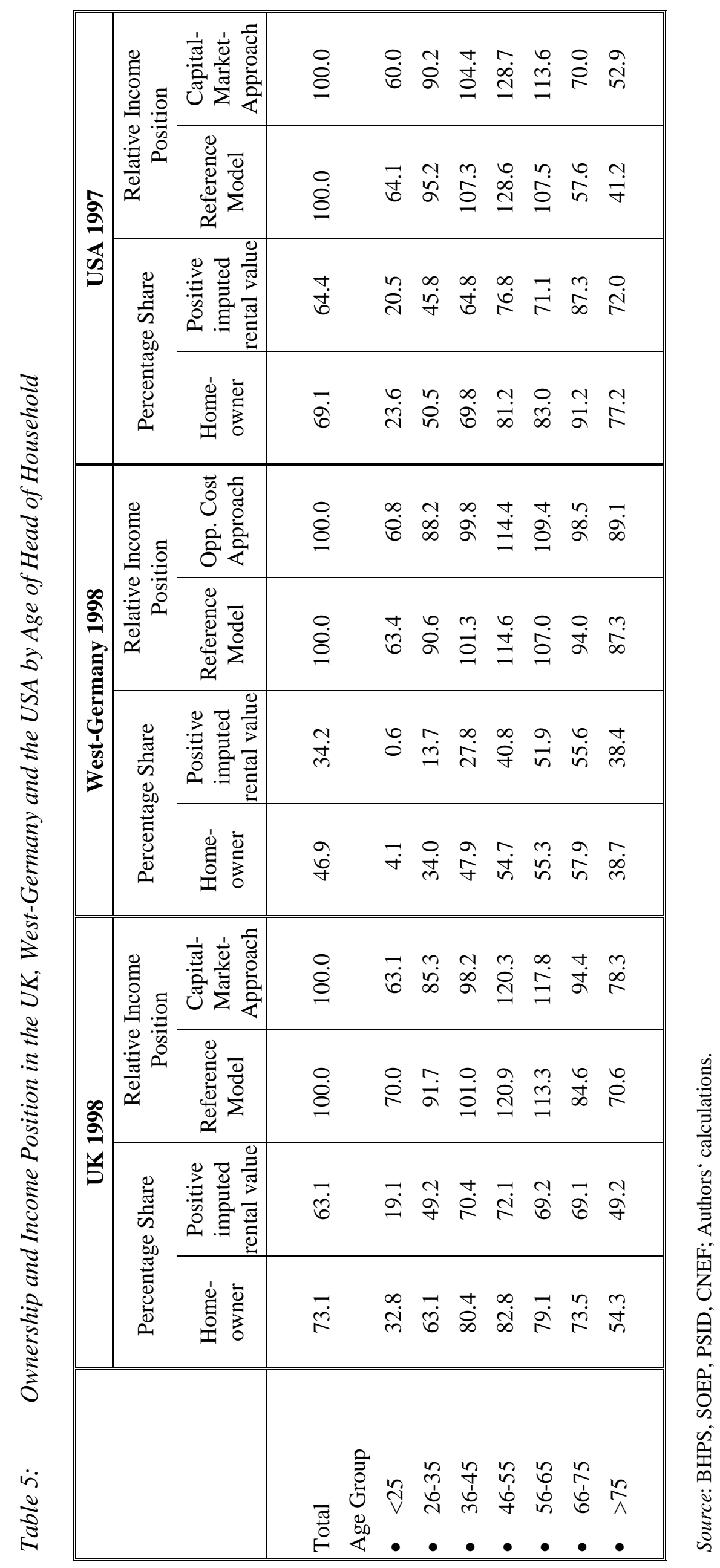




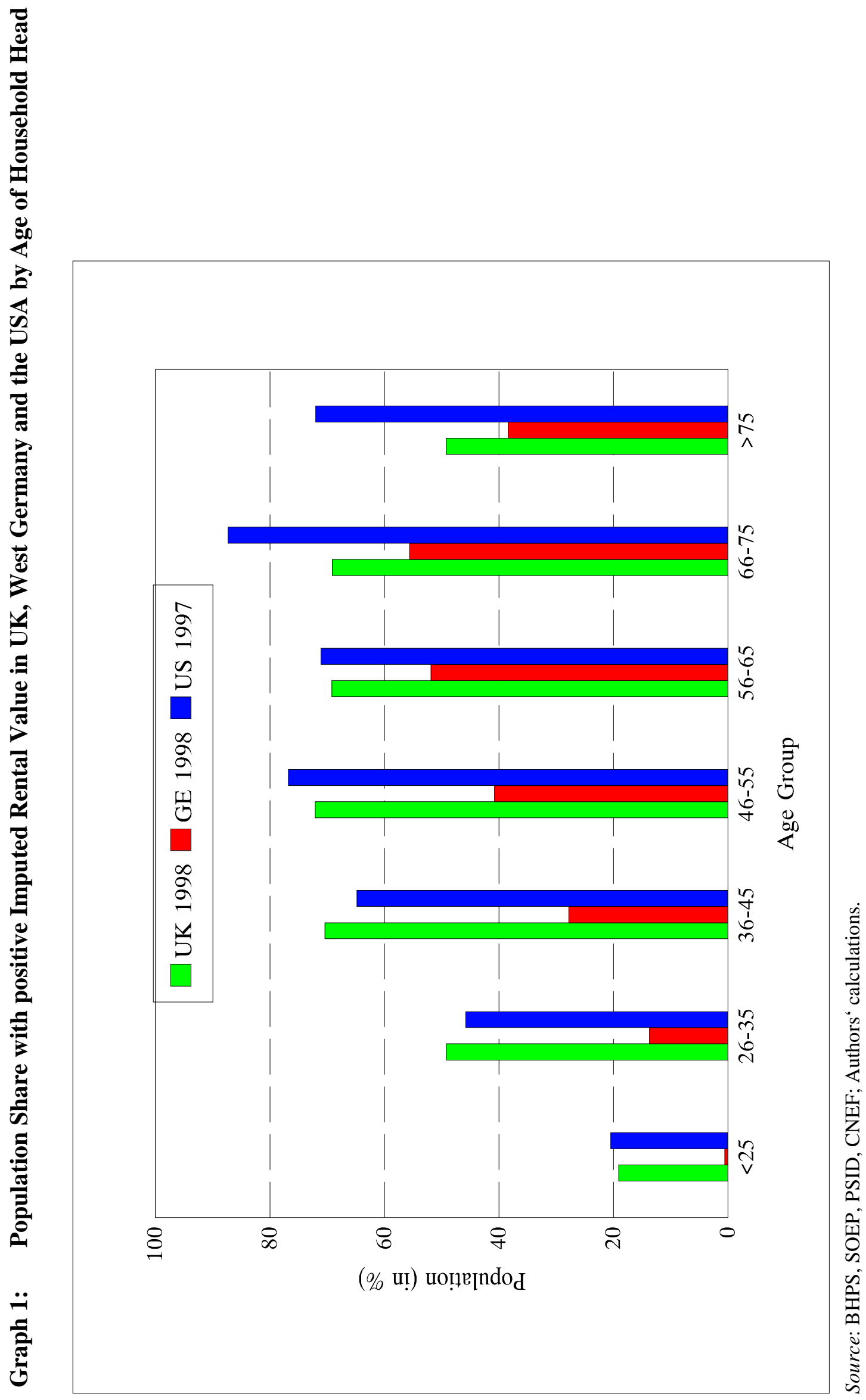




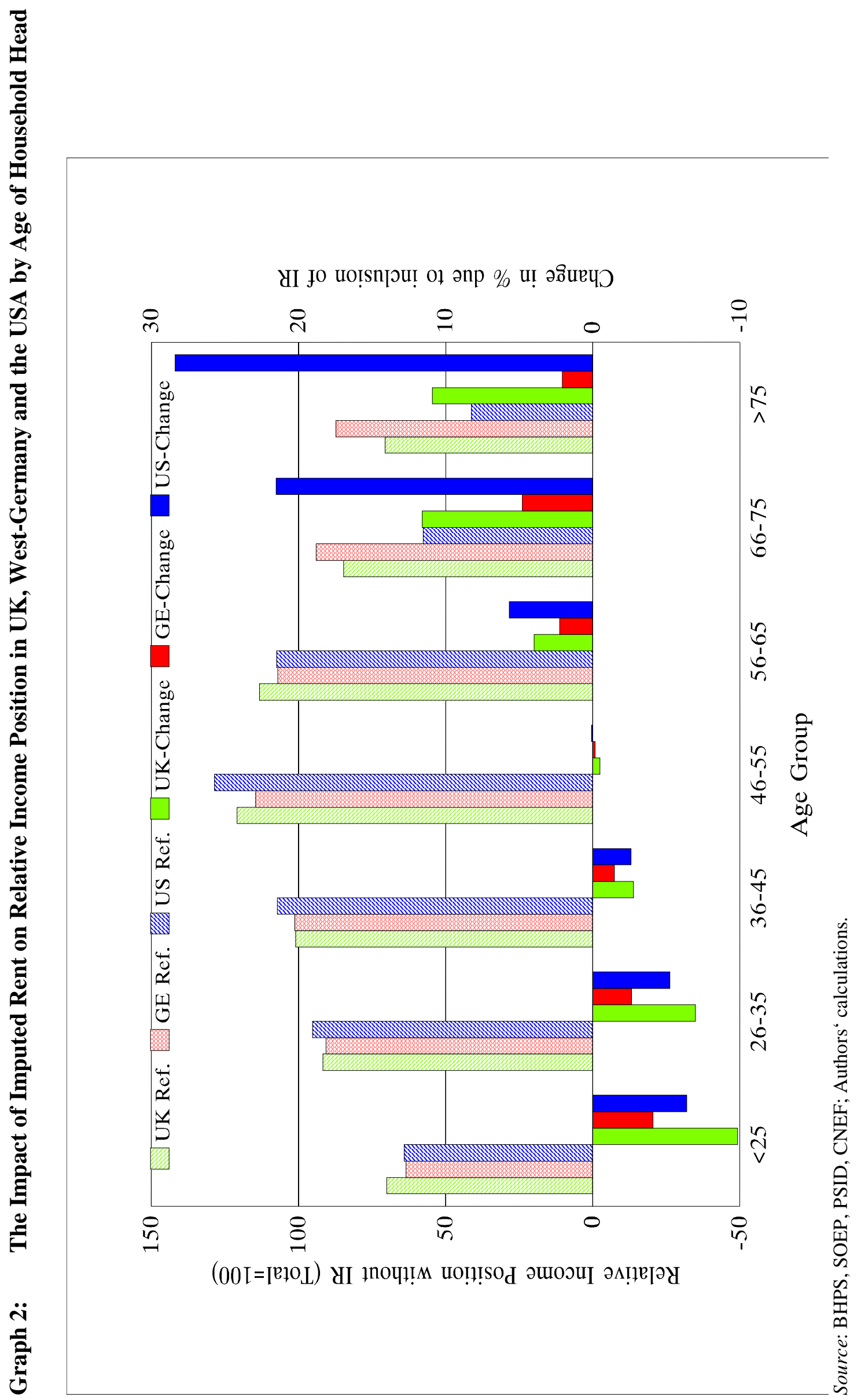

